Journal of Business \& Management (COES\&RJ-JBM)

ISSN (E): 2306-7179 ISSN (P): 2306-8043

Publisher: Centre of Excellence for Scientific \& Research Journalism, COES\&RJ LLC

Online Publication Date \& Issue: 1st January 2018, Vol.6, No.1, January 2018

https://doi.org/10.25255/jbm.2018.6.1.46.65

\title{
Job performance of selected accrediting agencies employees: Towards a job satisfaction measurement framework
}

\author{
Jocelyn DS. Malang, DBA \\ Ferdinand C. Somido, PhD \\ Susana C. Bautista, EdD \\ Pedrito Jose V. Bermudo, PhD \\ Antonio D. Yango, PhD \\ Leomar S. Galicia, PhD
}

\begin{abstract}
:
This study used the descriptive method of research using interview and questionnaire as research technique and instrument to assess and determine the different Philippine accrediting bodies' empowerment or managerial support that influenced the employee's job satisfaction and performance. Moreover, the researchers were interested to determine the respondents' positive and constructive feedback on the employee's compensation, fringe benefits, promotion, working environment and the like.

The results revealed that the respondents' perception on administrators' empowerment that support job satisfaction in terms of administrator as a manager, a corporate leader, fiscal manager, and link between company and community relation was "very much empowering." The respondents' satisfaction affected their job performance in terms of nature of work, supervision, operating condition, contingent reward, co-workers, professional development, promotion, pay and fringe benefits. Release of incentives, salary increase, change management, slow turnover, staff development, remuneration package, limited leave, no work no pay were identified by the respondents to affect their job performance.
\end{abstract}

\section{Keywords:}

job performance, accrediting agencies, job satisfaction measurement framework

\section{Citation:}

Malang, Jocelyn DS.; Somido, Ferinand C.; Bautista, Susana C.; Bermudo, Pedrito Jose V.; Yango, Antonio D.; Galicia, Leomar S. (2018); Job performance of selected accrediting agencies employees: Towards a job satisfaction measurement framework; Journal of Business \& Management (COES\&RJ-JBM) Vol.6,No.1,pp.46-65, https://doi.org/10.25255/jbm.2018.6.1.46.65.

This work is licensed under a Creative Commons Attribution 4.0 International License. 


\section{Introduction}

Job satisfaction represents one of the most complex areas facing today's managers when it comes to managing their employees. Many studies have demonstrated an unusually large impact on the job satisfaction on the motivation of workers, while the level of motivation has an impact on productivity, and hence also on performance of business organizations. There is a considerable impact of the employees' perceptions for the nature of his work and the level of overall job satisfaction. For example, financial compensation has a great impact on the overall job satisfaction of employees.

Today, every organization has to face highly competition. Therefore organizations try to do right thing at the right time. In that situation, administrators plays major roll to achieve organizational goals. Satisfaction is the one of major concept in Human Resource Management. Employee satisfaction is a measure of how happy workers are with their job and working environment. Keeping morale high among workers can be of tremendous benefit to any company, as happy workers will be more likely to produce more, take fewer days off, and stay loyal to the company. There are many factors in improving or maintaining high employee satisfaction, which wise employers would do well to implement. Job satisfaction is not the same as motivation, although it is clearly linked. Job design aims to enhance job satisfaction and performance; methods include job rotation, job enlargement and job enrichment. Other influences on satisfaction include the management style and culture, employee involvement, empowerment and autonomous work groups, pay, work responsibilities, variety of tasks, promotional opportunities the work itself and co-workers.

There are several accrediting agencies in the country catering to the various HEls. The Federation of Accrediting Agencies in the Philippines is the umbrella organization of three accrediting agencies in the Philippines namely the (1) Philippine Accrediting Association of Schools, College, and Universities (PAASCU); (2) Philippine Association of College and Universities Commission on Accreditation (PACU-COA); and (3) Association of Christian Schools, Colleges, and Universities Accrediting Agency, Inc. (ACSCU-AAI).

The Philippine Association of Colleges and Universities Commission on Accreditation (PACUCOA) is one of accrediting agencies in the country. Membership to this agency is open to all schools that are able to meet the standards and requirements of the agency. PACUCOA is a private accrediting agency which gives formal recognition to an educational institution by attesting that its academic program maintains excellent standards in its educational operations. PACUCOA was certified under ISO9001:2008 in 2009 and underwent its recertification audit in May 2015 and consequently passed the audit in flying colors. This certification will benefit not the agency alone, but also the institutions that are accredited by PACUCOA. It should be noted that if PACUCOA is certified by an international certifying body, it means that the quality of the organization complies with international standards. Thus, institutions accredited by PACUCOA, as well can have an assurance of high quality services from the agency.

PAASCU stands for Philippine Accrediting Association of Schools, Colleges and Universities. It is a private, voluntary, non-profit and non- stock corporation which was 
registered with the Securities and Exchange Commission on November 5, 1957. PAASCU is a service organization that accredits academic programs which meet standards of quality education. In November 1967, the Bureau of Education and Culture (now the Department of Education) officially recognized PAASCU and endorsed its work as an accrediting agency. PAASCU is also one of the three founding members of the Federation of Accrediting Agencies of the Philippines (FAAP), which was established in 1977 and is authorized by the Commission on Higher Education (CHED) to certify the levels of accredited programs for the purpose of granting progressive deregulation and other benefits. PAASCU has been a full member of the International Network for Quality Assurance Agencies in Higher Education (INQAAHE) and Asia-PAcific Quality Network (APQN), with PAASCU being one of its active members.

The Association of Christian Schools, Colleges and Universities (ACSCU) was established in 1946. It recognizes and commits itself to the sacred task of providing quality Christian education and promoting among its members a sense of unity, understanding and fellowship for better service to the community. The members are non-stock and nonprofit Protestant founded schools or institutions in the Philippines which are affiliated with Christian churches or denominations. Each includes the teaching of the Holy Bible as part of its curricula, particularly teaching that Jesus Christ is the only Incarnate Son of God. All revenues and grants received are utilized for educational services to the students.

ACSCU is a founding member of the Coordinating Council of Private Educational Associations (COCOPEA). It cooperates with the COCOPEA member associations, namely: the Catholic Educational Association of the Philippines (CEAP), the Philippine Association of Colleges and Universities (PACU), the Philippine Association of Private Schools, Colleges and Universities (PAPSCU), and the Technical-Vocational Schools Association of the Philippines (TEVSAPHIL). ACSCU is still a growing association. At present it consists only of one hundred eighteen (118) member schools spread in 16 regions of the country, six universities, three seminaries, 40 colleges, and 69 basic education schools

Accreditation is a concept of self-regulation which focuses on self-study and evaluation and on the continuing improvement of educational quality. It is both a process and a result. As a process, it is a form of peer review in which an association of schools and colleges establishes sets of criteria and procedures to encourage high maintenance of standards of education among its affiliate members. As a result, it is a form of certification granted by a recognized and authorized accrediting agency to an educational program or to an educational institution as possessing certain standards of quality which are over and above those prescribed as minimum requirements for government recognition. Accreditation is based upon an analysis of the merits of educational operations in the context of the institution's philosophy and objectives.

With the three mention accrediting bodies, it is inevitable that these companies work very hard to sustain their employee as pressure and sleepless nights becoming part of their life. Studies shows that though salary matters, staff will not stay in the company if they are not happy with their environment, no friends, no laugh and no social life. These factors affect their staying years in the organization, thus the level of satisfaction must be 
measured to determine or unmask what lies ahead among employees. The determination of their satisfaction level encouraged the management to protect and/or change policy for their employees for the better. Executive or senior leader in the company needs to be an enthusiastic champion and supportive of the new process, communicate its value and engage others to participate. Administrator in a company, have a responsibility to recognize and reinforce strong performance in employees, and identify and encourage improvement where needed.

The main purpose of this study was to assess and determine the different accrediting body's empowerment or managerial support that influences on the employee's job satisfaction and performance. The reason is that the company is an agency of assessing quality; the researchers wants to know if the employees are satisfied with the support and management of the administrators. Moreover, the researchers are interested to determine the positive and constructive feedback on the employee's compensation, fringe benefits, promotion, working environment and the like.

\section{Methods}

This study used the descriptive method of research using questionnaires as the main source of data. This method was used because the researcher believe that it will give a complete analysis and report of the employee's job satisfaction and performance of different accrediting agency such as PACUCOA, PAASCU, ACSCU-AAI. Descriptive research refers to the type of research question, design, and data analysis that will be applied to a given topic. The type of question asked by the researcher was ultimately determined the type of approach necessary to complete an accurate assessment of the topic at hand. Descriptive studies primarily concerned with finding out "what is". It is concerned with the point of view or attitudes that are held and process that are going on. Descriptive studies are of large value in providing facts on which scientific judgment is based. They play a great role in the development of instruments for measurement of many things, instruments that are employed in all types of quantitative research. To gather the needed information, the survey method was used. The potential of survey research lies in the questionnaire, which empowers the researcher to collect every kind of data to answer every question about the topic (Hamayun: 2014)

Forty five employees from three different accrediting agencies are conveniently selected as respondents of the study. The employees are selected regardless of their status whether probationary, contractual, or regular. The researchers used her contacts to different schools to help and to facilitate in giving the questionnaires to the people working on other accrediting agencies. Other were done thru email and seeking help to our colleague from different accrediting agencies. The profile of the respondents was categorized as to unit, age, sex, and civil status and number of years of service in the company. Respondents of the study are strictly from employees of the three accrediting agencies only. Since the number of employee is limited in numbers, all the responses of the employees who voluntarily answers the questionnaire are greatly appreciated. The varying numbers of respondents from the three accrediting agencies will not affect the general results since their response will be treated as group $f$ employee under the accrediting agencies of the Philippines. 
The researchers used a semi-structured interview questionnaire. A semi-structured interview is a qualitative method of inquiry that combines a pre-determined set of open questions with the opportunity for the interviewer to explore particular themes or responses further. It does not limit respondents to a set of pre-determined answers. Semi-structured interviews were used to understand how interventions work and how they could be improved. It also allows respondents to discuss and raise issues that you may not have been considered. In addition, open questioning helped the researchers to explore the topic and produce a fuller account of the response. With this, the interviewees were encouraged to clarify vague statements and further elaboration on brief comments. The researcher did not share her own beliefs and opinions so as not to influence the answer of the interviewee. During the face-to-face interview, the distribution and collation were used to manage the process and ensured anonymity. Moreover, the interview utilized a question and answer format. Lastly, the data gathered were recorded within 30 to 45 minutes after the semi-structured interview session with each participant. The recorded interview has transcribed by the researcher and the content was analyzed. The interview guide used is the same structure of the questionnaire sent to all the respondents.

The questionnaire formulated by the researchers used in this study was distributed personally. The researchers relied on the responses of the subject to the questionnaire, and on some information that were gathered during the interview. The first part of the questionnaire contains questions about personal information of the respondents. The questionnaire contains forty (40) items from 50 items based on validation using cronbach alpha. The second part of the survey determines the respondents' perception on the administrators' empowerment. All responses were measured using a 5-point Likert scale, ranging from one (1) not empowered and five (5) very much empowered. The third part of the survey is ten (10) criteria item that determines the respondents' job satisfaction on the demographic, Nature of work, Supervision, Operating Condition, Contingent Reward, Co-workers, professional development, Promotion, Pay and Fringe Benefits. It also includes an open ended question intended to get feedback on the problems encountered and suggestions of the respondents.

The questionnaire was subjected to validation by administering it to purposively selected 3 trial respondents from employees who were not be included in the final administration of data and check by the Adviser several times. Furthermore, a dry run was conducted to ascertain the clarity of the contents, and the procedures, and the instructions were given in the conduct of the final data-gathering. All comments and suggestions were given by the trial respondents were incorporated in the final copy of the questionnaire. Then, the revised questionnaire was reproduced and distributed to the target respondents of the study.

When a questionnaire is used as a data gathering instrument, it is necessary to determine whether questions and directions are clear to subjects and whether they understand what is required from them. This is referred to as the pretesting of a questionnaire (Polit \& Hungler 2013:). Cronbach's alpha reliability coefficient normally ranges between 0 and 1 . George and Mallery (2003) provide the following rules of 
thumb: $\alpha \geq .9$ - Excellent, .7 $\leq \alpha<.9$ - Good, .6 $\leq \alpha<.7$ - Acceptable, $.5 \leq \alpha<.6-$ Poor and $\alpha<.5-$ Unacceptable. If there are vague items, the questions were revised based on cronbach alpha. Cronbach's alpha provides a useful lower bound on reliability and measures internal consistency. It generally increases when the correlations between the items increase. Alpha coefficient measures the internal consistency of the system. Its maximum value is 1 , and usually its minimum value is 0 . A commonly-accepted rule of thumb is that an alpha of 0.6 indicates acceptable reliability and 0.7 or higher indicates good reliability (Tavakol \& Dennick, 2011). Crobach's Alpha is used to measure the internal consistency and acceptability of all the questionnaires in the survey form. In particular, it was used for testing with a score between 0 and 1.

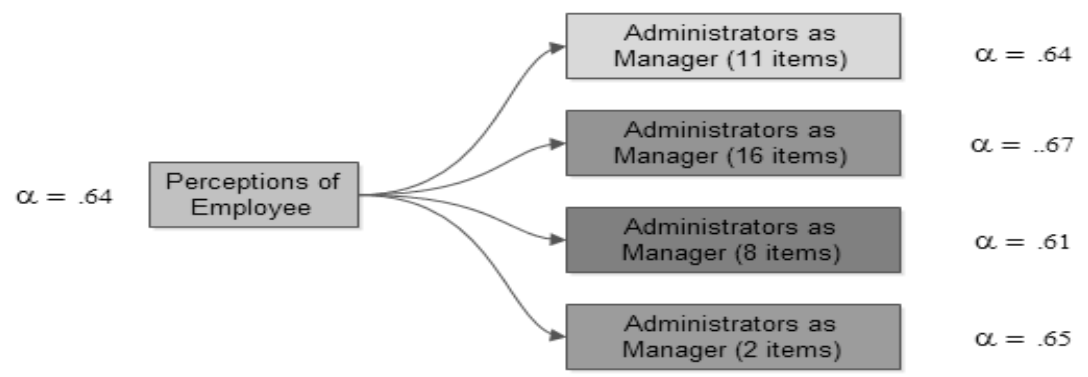

Figure 3.1: Cronbach Alpha of the Perceptions Questionnaire in the Survey

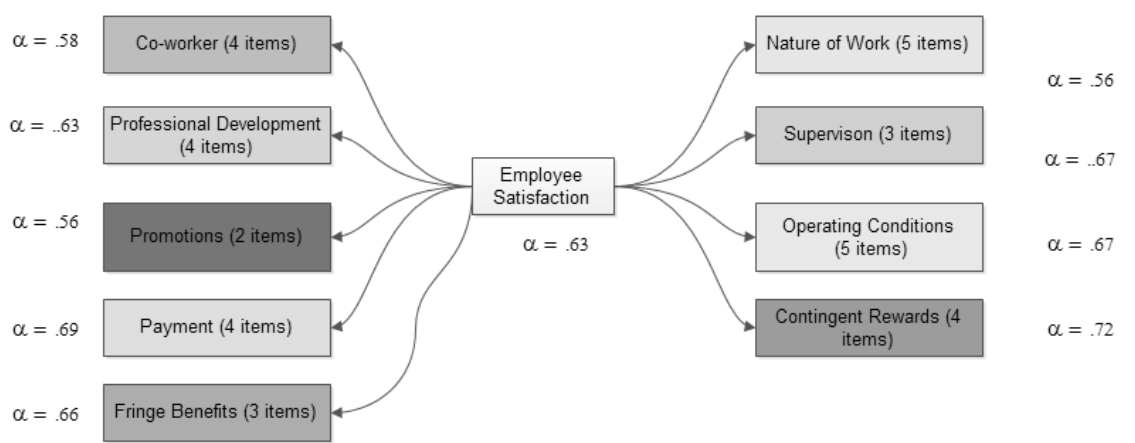

Figure 3.2: Cronbach Alpha of the Employee Satisfaction Questionnaire in the Survey

Figure 3.1 and Figure 3.2 provides the measurement and validation of the questionnaire before it was distributed among the respondents. The survey form were divided into two major items, the perceptions and job satisfaction. For the perceptions, 37 items were tested using the cronbach alpha and reveals the following alpha value of .64 which is generally acceptable. The cronbach alpha of the job satisfaction survey form is .63 and also acceptable.

In the conduct of the study researchers undertook several procedures such as securing a permission to conduct interview or administering the questionnaires. Data collection was done during the actual interview, after administering the questionnaires and some preferred to submit their answers through email.

\section{RESULTS}


1. What are the perceptions of the employees about administrator empowerment to support job satisfaction in terms of:

1.1 Administrator as a manager

Table 4.1 presents the assessment of the respondents on the administrator's empowerment in terms of administrator as a manager. It can be noted that the respondents assessment on administrators empowerment in terms of administrator as a manager has a composite mean of 4.72 with a verbal interpretation of "Very much empowered". All of the indicators have a mean scores of more than 4.55 which means that the administrators of the different accrediting agency as a manager is very much empowered in the organization. Also, all employees of all accrediting agency are all agreed that their administrators have very much empowered as a "Planner of Company's Programs and Projects" and Developing Human Resources".

Table 4.1: Assessment of Respondents on administrator's empowerment in terms of Administrator as a Manager

\begin{tabular}{|l|c|c|c|}
\hline \multicolumn{1}{|c|}{ Indicators } & WM & VI & Rank \\
\hline $\begin{array}{l}\text { Develops an action plan for programs and projects in accordance } \\
\text { with formulated company mission and objectives }\end{array}$ & 4.81 & VME & 2 \\
\hline Formulated objectives for programs and projects. & 4.81 & VME & 2 \\
\hline Prioritizes the need of the company. & 4.81 & VME & 2 \\
\hline $\begin{array}{l}\text { Maximizes the income Generating Process (IGP) for funding } \\
\text { special projects and programs. }\end{array}$ & 4.71 & VME & 6 \\
\hline $\begin{array}{l}\text { Monitors and evaluates the existing program for company's } \\
\text { development. }\end{array}$ & 4.67 & VME & 8.5 \\
\hline $\begin{array}{l}\text { Maintains the company Basic Management Information System } \\
\text { (BMIS). }\end{array}$ & 4.76 & VME & 4.5 \\
\hline $\begin{array}{l}\text { Imposes administrative devices within the company premise like } \\
\text { improvement; maintenance and acquisition of company facilities } \\
\text { and equipment. }\end{array}$ & 4.76 & VME & 4.5 \\
\hline Oversees implementation of the company based programs. & 4.67 & VME & 8.5 \\
\hline Decides for the promotion of employees and staff. & 4.67 & VME & 8.5 \\
\hline $\begin{array}{l}\text { Delegates powers to align responsibilities and duties to his/her } \\
\text { staff. }\end{array}$ & 4.67 & VME & 8.5 \\
\hline $\begin{array}{l}\text { Imposes disciplinary measures and sanctions to every employee } \\
\text { and staff. }\end{array}$ & 4.62 & VME & 11 \\
\hline \multicolumn{1}{|c|}{ Composite Mean } & 4.72 & VME & \\
\hline
\end{tabular}

The data revealed that three (3) out of eleven (11) indicators show a mean score of 4.81 which means, very much empowered. As specified in the table, these indicators ranked number 1 . These are: "Develops an action plan for programs and projects in accordance with formulated company mission and objectives"; "Formulated objectives for programs and projects"; and "Prioritizes the need of the company".

There are two (2) items that obtained a mean score of 4.76 which means very much empowered. These are: "Maintains the company Basic Management Information System (BMIS)"; and "Imposes administrative devices within the company premise like improvement, maintenance and acquisition of company facilities and equipment". It was noted that these indicators ranked number 4.5 . It was followed by ranked number 6 , 
"Maximizes the income Generating Process (IGP) for funding special projects and programs" with a mean score of 4.71 .

There are four (4) items ranked number 8.5 with a mean score of 4.67 . These are: "Monitors and evaluates the existing program for company's development"; Oversees implementation of the company based programs"; "Decides for the promotion of employees and staff"; and "Delegates powers to align responsibilities and duties to his/her staff". The last indicator has the lowest mean score. "Imposes disciplinary measures and sanctions to every employee and staff" has a mean score of 4.62. Although this indicator has a lowest score and ranked 11, but the verbal interpretation for this item is "Very much empowered".

1.2 Administrator as a Corporate Leader

Table 4.2 - Assessment of Respondents on administrator's empowerment in terms of Administrator as a Corporate Leader

\begin{tabular}{|l|c|c|c|}
\hline \multicolumn{1}{|c|}{ Indicators } & WM & VI & Rank \\
\hline Manages the development and promotion of the system. & 4.48 & ME & 16 \\
\hline Assigns staff to their area of competence. & 4.52 & ME & 15 \\
\hline $\begin{array}{l}\text { Organizes seminar and in-service training on the use of different } \\
\text { strategies and for the development of skills and talents. }\end{array}$ & 4.71 & VME & 10 \\
\hline $\begin{array}{l}\text { Implements system change depending on the need and context } \\
\text { parallel to the mission, vision goal and objectives of PACUCOA and } \\
\text { ISO standards. }\end{array}$ & 4.76 & VME & 5.5 \\
\hline $\begin{array}{l}\text { Uses the evaluated performance evaluation results and uses as basis } \\
\text { for merit increases. }\end{array}$ & 4.71 & VME & 10 \\
\hline $\begin{array}{l}\text { Encourages to develop and innovate for further improvement of } \\
\text { PACUCOA. }\end{array}$ & 4.81 & VME & 2 \\
\hline Motivates staff to participate in outreach programs. & 4.81 & VME & 2 \\
\hline Promotes a caring -learning -friendly working atmosphere. & 4.81 & VME & 2 \\
\hline Promotes technology literacy. & 4.76 & VME & 5.5 \\
\hline $\begin{array}{l}\text { Develops learning resource and service centers- facilities for physical } \\
\text { improvement and staff development. }\end{array}$ & 4.71 & VME & 10 \\
\hline Imposes relevant trainings of activities assigned to each staff. & 4.76 & VME & 5.5 \\
\hline Recruits /recommends manpower for office operation. & 4.67 & VME & 13 \\
\hline Hire additional and replacement of staff. & 4.76 & VME & 5.5 \\
\hline Approves extension of vacation / sick leave privileges to staff. & 4.62 & VME & 14 \\
\hline $\begin{array}{l}\text { Prepares and designs training program for staff development at } \\
\text { least once a year. }\end{array}$ & 4.71 & VME & 10 \\
\hline Recommends staff for career advancement. & 4.71 & VME & 10 \\
\hline \multicolumn{1}{|c|}{ Composite Mean } & 4.71 & VME & \\
\hline
\end{tabular}

As shown in the Table, the data revealed that the respondents' assessment on administrators empowerment in terms of administrator as a corporate leader has a composite mean of 4.71 with a verbal interpretation of very much empowered. There were three (3) indicators that fall under ranked 2. These are: "Encourages to develop and innovate for further improvement of PACUCOA"; "Motivates staff to participate in 
outreach programs"; and "Promotes a caring -learning -friendly working atmosphere". These indicators have a mean score of 4.81 which means very much empowered.

It was followed by four indicators that are ranked number 5.5, these are: "Implements system change depending on the need and context parallel to the mission, vision goal and objectives of PACUCOA and ISO standards"; "Promotes technology literacy"; "Imposes relevant trainings of activities assigned to each staff; and Hire additional and replacement of staff". These indicators have a mean score of 4.76 which means very much empowered. The next five (5) indicators have the same weighted mean of 4.71 . These indicators are ranked 10. These are: "Organizes seminar and in-service training on the use of different strategies and for the development of skills and talents"; "Uses the evaluated performance evaluation results and uses as basis for merit increases"; "Develops learning resource and service centers- facilities for physical improvement and staff development"; "Prepares and designs training program for staff development at least once a year"; and "Recommends staff for career advancement". It is also noted that the indicator "Recruits/recommends manpower for office operation" has a mean score of 4.67 which means very much empowered. This indicator is ranked 13. "Approves extension of vacation / sick leave privileges to staff" is ranked 14 with a mean score of 4.62 followed by "Assigns staff to their area of competence" with a mean score of 4.52.The last indicator with a mean score of 4.48 is "Manages the development and promotion of the system" which is interpreted as much empowered.

\subsection{Fiscal Manager}

Table 4.3: Assessment of Respondents on administrator's empowerment in terms of Fiscal Manager

\begin{tabular}{|c|c|c|c|}
\hline Indicators & WM & VI & Rank \\
\hline $\begin{array}{l}\text { Prepared, defends, implements and accounts for the company's budget } \\
\text { stated in a financial management plan. }\end{array}$ & 4.76 & VME & 2 \\
\hline $\begin{array}{l}\text { Initiates Income Generating Projects (IGP) to maximize the company's } \\
\text { resources. }\end{array}$ & 4.67 & VME & 5.5 \\
\hline Uses proceeds of (IGP) for employees development. & 4.62 & VME & 7.5 \\
\hline Realigns funds for company priority projects. & 4.71 & VME & 4 \\
\hline $\begin{array}{l}\text { Allocates funds for improvement and maintenance of company physical } \\
\text { facilities. }\end{array}$ & 4.76 & VME & 2 \\
\hline $\begin{array}{l}\text { Has an autonomy and finality in financial matters concerning the } \\
\text { company's expenditures. }\end{array}$ & 4.67 & VME & 5.5 \\
\hline $\begin{array}{l}\text { Identifies and taps alternatives of funding to help projects and activities } \\
\text { for employees development. }\end{array}$ & 4.62 & VME & 7.5 \\
\hline $\begin{array}{l}\text { Accounts for company's funds and expenditures and prepare financial } \\
\text { report for transparency. }\end{array}$ & 4.76 & VME & 2 \\
\hline Composite Mean & 4.70 & VME & \\
\hline
\end{tabular}

As reflected in the table, the respondents' assessment on administrators' empowerment in terms of fiscal manager has a composite mean of 4.70 with a verbal interpretation of Very much empowered. Also, the data revealed that three (3) out of eight (8) indicators shows a mean score of 4.76 which means, very much empowered. As specified in the table, these indicators are all ranked 2. These are the following: "Prepared, defends, implements and accounts for the company's budget stated in a financial management 
plan"; "Allocates funds for improvement and maintenance of company physical facilities"; and "Accounts for company's funds and expenditures and prepare financial report for transparency". It is also revealed that the indicator "Realigns funds for company priority projects" was ranked 4. This indicator has a mean score of 4.71. Furthermore, two (2) of the indicators have a mean score of 4.67 which ranked 5.5. These are: "Initiates Income Generating Projects (IGP) to maximize the company's resources"; and "has an autonomy and finality in financial matters concerning the company's expenditures".

The last two indicators have a mean score of 4.62. These items have a verbal interpretation of much empowered. These indicators are the following: "Uses proceeds of (IGP) for employees' development"; and "Identifies and taps alternatives of funding to help projects and activities for employees development".

Table 4.4 - Assessment of Respondents on administrator's empowerment in terms of Link Between Company and Community Relation

\begin{tabular}{|l|l|c|c|}
\hline \multicolumn{1}{|c|}{ Indicators } & WM & VI & Rank \\
\hline Networks with private sector for company projects development. & 4.57 & VME & 4 \\
\hline Links with LGU's, GO's and NGO's for fund sourcing. & 1.81 & NME & 5 \\
\hline $\begin{array}{l}\text { Fosters relationship with member school and community to promote } \\
\text { positive image. }\end{array}$ & 4.71 & VME & 1.5 \\
\hline $\begin{array}{l}\text { Negotiates for the needed resources and determine community } \\
\text { needs. }\end{array}$ & 4.71 & VME & 1.5 \\
\hline $\begin{array}{l}\text { Designs, implements and evaluates community outreached and } \\
\text { support community programs. }\end{array}$ & 4.62 & VME & 3 \\
\hline \multicolumn{1}{|c|}{ Composite Mean } & $\mathbf{4 . 0 9}$ & ME & \\
\hline
\end{tabular}

As shown in the table, the respondent's assessment on administrators' empowerment in terms of Link Between Company and Community Relation has a composite mean of 4.09 with a verbal interpretation of much empowered. Two (2) out of five (5) indicators are ranked 1.5. These items have a mean score of 4.71 which means very much empowered. These are the following: "Fosters relationship with member school and community to promote positive image"; and "Negotiates for the needed resources and determine community needs".

It is also revealed that the indicator "Designs, implements and evaluates community outreached and support community programs" has a mean score of 4.62 which is ranked 3. It is followed by ranked 4, "Networks with private sector for company projects development" with a score mean of 4.57 which means very much empowered. As you can see in the table, the lowest and the last indicator with a mean score of 1.81 is "Links with LGU's, GO's and NGO's for fund sourcing". This indicator has a verbal interpretation of "Not much empowered". The respondents did not observe that the administrator is not empowered with regards to linking with the Local Government Units, Government Units and Non-Government Organizations for fund sourcing.

\section{How do employees satisfaction affect their performance in terms of:}


Job performance of selected accrediting agencies employees: .....

2.1 Nature of Work

Table 4.5 - Employees' Performance in terms of Nature of Work

\begin{tabular}{|l|c|c|c|}
\hline \multicolumn{1}{|c|}{ Indicators } & WM & VI & Rank \\
\hline Working with quality is an interesting job for me. & 4.62 & ES & 1 \\
\hline I feel satisfied with my professional ability for doing my job. & 4.57 & ES & 2 \\
\hline $\begin{array}{l}\text { I am comfortable with the geographical location of the company in } \\
\text { which I work. }\end{array}$ & 4.43 & VS & 6 \\
\hline I feel comfortable with my present level of responsibility in my job. & 4.52 & VS & 4 \\
\hline Working with PACUCOA provides me with opportunity to use all my skills. & 4.52 & VS & 4 \\
\hline Working at PACUCOA is a challenging job for me. & 4.52 & VS & 4 \\
\hline \multicolumn{1}{|c|}{ Composite Mean } & $\mathbf{4 . 5 3}$ & VS & \\
\hline
\end{tabular}

It was depicted in Table 10 that the employees' satisfaction affects their performance in terms of Nature of Work which has a composite mean of 4.53 , with a verbal interpretation of very satisfied. The indicator "Working with quality is an interesting job for me" is ranked 1. This indicator has a mean score of 4.62 which means Extremely Satisfied. The second indicator "I feel satisfied with my professional ability for doing my job" was ranked 2 with a mean score of 4.57 which is also interpreted Extremely Satisfied. It is also revealed that three (3) out of six (6) indicators are all ranked 4 . These indicators have a mean score of 4.52 which means Very Satisfied. These are the following: "I feel comfortable with my present level of responsibility in my job"; "Working with PACUCOA provides me with opportunity to use all my skills"; and "Working at PACUCOA is a challenging job for me. The last indicator "I am comfortable with the geographical location of the company in which I work" is ranked 6 and has a mean score of 4.43 . With this, the respondents are extremely satisfied in all the indicators in terms of nature of work.

\subsection{Supervision}

Table 4.6 - Employees Performance in terms of Supervision

\begin{tabular}{|c|c|c|c|}
\hline \multicolumn{1}{|c|}{ Indicators } & WM & VI & Rank \\
\hline I am satisfied with care I receive from my immediate supervisor(s) & 4.67 & ES & 1 \\
\hline I am satisfied with support I get from executive director. & 4.62 & ES & 2.5 \\
\hline I am happy with support I receive from the Commissioner. & 4.62 & ES & 2.5 \\
\hline Composite Mean & $\mathbf{4 . 6 3}$ & ES & \\
\hline
\end{tabular}

It is revealed that the employees' satisfaction affect their performance in terms of supervision has a composite mean of 4.63 with a verbal interpretation of extremely satisfied. As depicted in the table, the data shows that all indicators are rated Extremely Satisfied. Ranked one is "I am satisfied with care I receive from my immediate supervisor(s)" with a mean score of 4.67. The last two indicators have an equal mean score of 4.62. These indicators ranked number 2.5 in the list. These are the following: "I am satisfied with support I get from executive director"; and "I am happy with support I receive from the Commissioner". The result shows that they are satisfied and happy with their supervisors.

\subsection{Operating Condition}

Table 4.7 - Employees Performance in terms of Operating Condition 


\begin{tabular}{|l|c|c|c|}
\hline \multicolumn{1}{|c|}{ Indicators } & WM & VI & Rank \\
\hline $\begin{array}{l}\text { I am satisfied with the regulations and laws that protect me from being fired or } \\
\text { dismissed from my job e.g. employment contract. }\end{array}$ & 4.52 & VS & 3 \\
\hline I am satisfied with autonomy I have in making decisions about my daily tasks. & 4.52 & VS & 3 \\
\hline I enjoyed much freedom in my place of work. & 3.53 & MS & 5 \\
\hline I feel protected against arbitrary dismissal from my current employment. & 4.52 & VS & 3 \\
\hline I would not like to be transferred to another company. & 4.57 & ES & 1 \\
\hline \multicolumn{1}{|c|}{ Composite Mean } & 4.51 & VS & \\
\hline
\end{tabular}

A shown in table 4.7, It is revealed that the employees satisfaction affect their performance in terms of operating condition has a composite mean of 4.51 with a verbal interpretation of very satisfied. Also, it is reveal that the last indicator is ranked 1 . The item "I would not like to be transferred to another company" has a mean score of 4.57 which means extremely satisfied. This ranking is followed by ranked 3 by three (3) out of five (5) indicators. These three items have a mean score of 4.52 , which means very satisfied and these are the following: "I am satisfied with the regulations and laws that protect me from being fired or dismissed from my job e.g. employment contract"; "I am satisfied with autonomy I have in making decisions about my daily tasks"; and "I feel protected against arbitrary dismissal from my current employment". Ranked 5 has a mean score of 3.43 which means moderately satisfied. Finally, the respondents are contented and extremely satisfied in all the indicators stated in the table specifically in their place of work.

\subsection{Contingent Reward}

Table 4.8 - Employees Performance in terms of Contingent Reward

\begin{tabular}{|l|c|c|c|}
\hline \multicolumn{1}{|c|}{ Indicators } & WM & VI & Rank \\
\hline $\begin{array}{l}\text { I feel comfortable with rewards I get for doing a good job in the } \\
\text { PACUCOA. }\end{array}$ & 4.71 & ES & 1 \\
\hline I feel satisfied with bonuses I receive from my employer. & 4.52 & VS & 3 \\
\hline I feel satisfied with the recognition I have in the PACUCOA. & 4.48 & VS & 4 \\
\hline $\begin{array}{l}\text { I am happy with the appreciations I get from employer for the } \\
\text { contribution I make in the PACUCOA. }\end{array}$ & 4.57 & ES & 2 \\
\hline \multicolumn{1}{|c|}{ Composite Mean } & $\mathbf{4 . 5 7}$ & ES & \\
\hline
\end{tabular}

It was revealed that the employees satisfaction affect their performance in terms of contingency reward which has a composite mean of 4.57, with a verbal interpretation of extremely satisfied. There are only four indicators in Table 4.8. It shows that the first indicator is ranked 1. This indicator is "I feel comfortable with rewards I get for doing a good job in the accrediting agency". The findings indicate that accrediting agency gives incentives. This item has a mean score of 4.71 which means extremely satisfied. Furthermore, the last indicator is ranked 2 with a mean score of 4.57 . This indicator is "I am happy with the appreciations I get from employer for the contribution I make in the PACUCOA". Appreciating the job well-done motivates the employees to perform well in their job. It is also noted that ranked number 3 has a mean score of 4.52 which means very satisfied. This indicator is "I feel satisfied with bonuses I receive from my employer". 
And the last in the ranked is "I feel satisfied with the recognition I have in the country" with a mean score of 4.48 which means very satisfied. This means that all respondents or employees are extremely satisfied with the contingency reward given by the accrediting agency.

\subsection{Co-Workers}

Table 4.9 - Employees Performance in terms of Co-Workers

\begin{tabular}{|l|c|c|c|}
\hline \multicolumn{1}{|c|}{ Indicators } & WM & VI & Rank \\
\hline $\begin{array}{l}\text { I am happy with cooperation I receive from the company } \\
\text { management team. }\end{array}$ & 4.33 & VS & 1 \\
\hline I am happy with the cooperation I receive from my workers. & 4.19 & VS & 4 \\
\hline My colleagues value my contribution in the PACUCOA & 4.29 & VS & 2 \\
\hline I enjoy friendly relationship with fellow employees. & 4.24 & VS & 3 \\
\hline \multicolumn{1}{|c|}{ Composite Mean } & 4.26 & VS & \\
\hline
\end{tabular}

It was depicted in the table that the employees satisfaction affect their performance in terms of Co-workers which has a composite mean of 4.26, with a verbal interpretation of very satisfied. Table 4.9 reveals that the first indicator is ranked 1 . This indicator is "I am happy with cooperation I receive from the company management team." This indicator has a mean score of 4.33 which means extremely satisfied, this manifest that the employer is very supportive. Ranked 2 has a mean score of 4.92. This indicator is "My colleagues value my contribution in the accrediting agency". The finding indicates that the employees have teamwork. It is also noted that the indicator "I enjoy friendly relationship with fellow employees" is ranked 3. This has a mean score 4.24 which means very satisfied. This was followed by ranked number 4 , with a mean score of 4.19 which means very satisfied. This is a manifestation that they have good camaraderie. This indicator is "I am happy with the cooperation I receive from my workers". As you can see, it shows that all respondents or employees of the agency are satisfied and happy with their co-workers.

\subsection{Professional Development}

Table 4.10 - Employees Performance in terms of Professional Development

\begin{tabular}{|l|c|c|c|}
\hline \multicolumn{1}{|c|}{ Indicators } & WM & VI & Rank \\
\hline $\begin{array}{l}\text { I am satisfied with opportunities for workshops organized within and outside } \\
\text { the company. }\end{array}$ & 3.33 & MS & 2 \\
\hline $\begin{array}{l}\text { I am satisfied with in service training opportunities available for me as an } \\
\text { employee. }\end{array}$ & 3.29 & MS & 3 \\
\hline $\begin{array}{l}\text { I feel satisfied with opportunities for training and professional development } \\
\text { available. }\end{array}$ & 3.38 & MS & 1 \\
\hline $\begin{array}{l}\text { I am satisfied with opportunities to attend seminars within and outside the } \\
\text { company. }\end{array}$ & 3.24 & MS & 4 \\
\hline \multicolumn{1}{|c|}{ Composite Mean } & 3.31 & MS & \\
\hline
\end{tabular}

It was revealed that the employees' satisfaction affect their performance in terms of professional development which has a composite mean of 3.31 with a verbal interpretation of moderately satisfied. It is depicted in the table that all the indicators are 
rated moderately satisfied but they vary in the weighted means. Ranked 1 is "I feel satisfied with opportunities for training and professional development available". This is followed "I am satisfied with opportunities for workshops organized within and outside the company" which has a mean score of 3.33. The third rank has a mean score of 3.29 which is "I am satisfied with in service training opportunities available for me as an employee". Last indicator is "I am satisfied with opportunities to attend seminars within and outside the company" which has a mean score of 3.24 which means moderately satisfied. As you can see in the table, all the indicators have a verbal interpretation of moderately satisfied which means that all respondents are not so happy in accrediting agency in terms of professional development.

\subsection{Promotion}

Table 4.11 - Employees Performance in terms of Promotion

\begin{tabular}{|l|c|c|c|}
\hline \multicolumn{1}{|c|}{ Indicators } & WM & VI & Rank \\
\hline $\begin{array}{l}\text { I am comfortable with the promotion opportunities available to me as } \\
\text { an employee }\end{array}$ & 4.24 & VS & 1 \\
\hline The Promotion process and procedure used by my employer are fair. & 4.24 & VS & 1 \\
\hline Composite Mean & $\mathbf{4 . 2 4}$ & VS & \\
\hline
\end{tabular}

It was revealed that the employees' satisfaction affects their performance in terms of promotion which has a composite mean of 4.24 and with a verbal interpretation of very satisfied. There are only two indicators in table 16. As depicted in the table, the two indicators have the same score mean of 4.24 which means Very Satisfied. These indicators are the following: "I am comfortable with the promotion opportunities available to me as an employee"; and "The Promotion process and procedure used by my employer are fair. This is also a manifestation that the respondents are agreed and comfortable in terms of promotion given by the accrediting agency. Malik, Danish and Munir (2015), studied the impact of pay and promotion on the job satisfaction presented in the higher education of Pakistan and eventually resulted to a minimal increased of salary.

\subsection{Pay}

Table 4.12 - Employees Performance in terms of Pay

\begin{tabular}{|l|c|c|c|}
\hline \multicolumn{1}{|c|}{ Indicators } & WM & VI & Rank \\
\hline The monthly salary is sufficient to meet all important expenses. & 4.19 & VS & 4 \\
\hline I feel comfortable with my future incomes. & 4.33 & VS & 3 \\
\hline I am not intending to look for another well-paying job in another company. & 4.43 & VS & 2 \\
\hline I feel fairly paid by my employer. & 4.48 & VS & 1 \\
\hline Composite Mean & $\mathbf{4 . 3 6}$ & VS & \\
\hline
\end{tabular}

As depicted in the table, the employees' satisfaction affects their performance in terms of pay which has a composite mean of 4.36, with a verbal interpretation of very satisfied. Also, It is showed that the indicator "I feel fairly paid by my employer is ranked 1 which has a mean score of 4.48 which means very satisfied. This manifest that the company follows the Labor Code. Second indicator is "I am not intending to look for another wellpaying job in another company". This indicates that the employees are contented with accrediting agency has a mean score of 4.43 . 
It is also noted that the indicators "I feel comfortable with my future incomes" and "the monthly salary is sufficient to meet all important expenses" are ranked 3 and 4, respectively. These indicators have mean scores of 4.33 and 4.19 respectively which means very satisfied. As you can see in the table, all respondents are agreed and feel comfortable with their salary that they received in the accrediting agency. Muranga (2016) in his study discussed the relationship between pay, job satisfaction and organizational commitment and found out that there is a big correlation of those factors just mentioned. Malik, Danish and Munir (2015), also studied the impact of pay and promotion on the job satisfaction presented in the higher education of Pakistan.

\subsection{Fringe Benefits}

Table 4.13 - Employees Performance in terms of Fringe Benefits

\begin{tabular}{|l|c|c|c|}
\hline \multicolumn{1}{|c|}{ Indicators } & WM & VI & Rank \\
\hline I feel happy with my present fringe benefits. & 4.43 & VS & 2 \\
\hline I am comfortable with my future fringe benefits & 4.48 & VS & 1 \\
\hline Composite Mean & $\mathbf{4 . 4 5}$ & VS & \\
\hline
\end{tabular}

It is revealed that the employees' satisfaction affects their performance in terms of fringe benefits which has a composite mean of 4.45 with a verbal interpretation of very satisfied. As shown in the table, the indicator "I am comfortable with my future fringe benefits" is ranked 1 . This indicator has a mean score of 4.48 which means very satisfied. The respondents are expecting that there will be future benefits that they will be receive from the company. It is followed by ranked 2 and last indicator "I feel happy with my present fringe benefits" with a score mean of 4.43. This means that both indicators have a verbal interpretation of very satisfied. But as you can see in the table, respondents are more comfortable with their future fringe benefits compare to their present fringe benefits.

3. What are the problems encountered by the respondents in their job as an employee? The problems encountered by the respondents in their present job as an employee are the following: there is no security of tenure and retirement package, frequent turnover of employees in some units, new employees must undergo casual basis for at least three (3) terms resulted that some employees must render at least less than two (2) years before they become regular, miscommunication and impolite caller, delayed letters, difficulty in implementation of management information system (MIS) and low internet connection, traffic congestion, time management, not following the existing style of work "first in, first out rule", difficult in prioritizing of work, late submission of documents to be used by the accreditors for accreditation, difficult to invite accreditors for accreditation visit, failure to beat the deadline, volume of documents to be checked everyday, attitude of co-employees, late submission of documents by the chairman of the accreditation visit.

The following are the suggested recommendations by the respondents: Security of tenure and retirement package for all regular employees must be reviewed and implemented, screening of at least three (3) to five (5) applicants in a particular position could be implemented, sending all employees into different trainings/seminar for personal and professional growth, upgrade the internet connection for faster processing of invitation, letters and other documents pertaining to accreditation, support and 
cooperation of supervisors and all staffs for fully implementation of Management Information System, advice the school to submit their documents on time to minimize the movement of date or cancelation of accreditation visit, give more time in the implementation of the changes so that the employee can cope with the new changes/tasks, in case there are employees who decided to resign, please give more time on turnover because not all employees are fast learner, full implementation of paperless environment, allow the school to communicate or submit their letters and documents in soft copy, encourage all chairmen of accreditation visit to submit their reports on - time to avoid delayed of reports.

4. Is there a significant differences on the different factors stated in problem 2 with regards to job satisfaction model?

To determine whether there is significant difference of some factors such as nature of work, supervision, environment, reward, co-workers, development, promotion, salary and fringe benefits against job satisfaction, nine respondents were taken in each accrediting bodies. The minimum number of employee is from ACSCU were nine employee responded to the questions.

Table 4.14: Respondents Mean and the Job Satisfaction Rating

\begin{tabular}{|c|c|c|c|c|c|c|c|c|c|}
\hline Nature of Work & Supervision & Environment & Reward & Co-Workers & Development & Promotion & Salary & Fringe Benefits & Job Satisfaction \\
\hline 3.00 & 5.00 & 4.00 & 5.00 & 4.00 & 4.00 & 3.00 & 4.00 & 5.00 & 90 \\
\hline 4.00 & 4.00 & 3.00 & 5.00 & 4.00 & 5.00 & 3.00 & 3.00 & 3.00 & 85 \\
\hline 4.00 & 5.00 & 4.00 & 3.00 & 4.00 & 5.00 & 4.00 & 4.00 & 4.00 & 86 \\
\hline 4.00 & 3.00 & 5.00 & 3.00 & 4.00 & 4.00 & 3.00 & 5.00 & 5.00 & 91 \\
\hline 3.00 & 4.00 & 3.00 & 4.00 & 5.00 & 5.00 & 4.00 & 5.00 & 5.00 & 95 \\
\hline 5.00 & 3.00 & 4.00 & 4.00 & 5.00 & 4.00 & 4.00 & 5.00 & 4.00 & 88 \\
\hline 3.00 & 4.00 & 5.00 & 3.00 & 4.00 & 3.00 & 3.00 & 3.00 & 3.00 & 87 \\
\hline 4.00 & 5.00 & 4.00 & 3.00 & 4.00 & 3.00 & 4.00 & 4.00 & 4.00 & 90 \\
\hline 5.00 & 4.00 & 3.00 & 5.00 & 4.00 & 3.00 & 3.00 & 3.00 & 5.00 & 95 \\
\hline
\end{tabular}

To even the correlation 9 responses were extracted from each accrediting body. From the table it can be shown that all the respondents graded the factors based on Lickert scale of 1-5 while the job satisfaction is graded between $0-100$.

Applying the pair correlation matrix of the nine factors, Table 4.15 shows the correlation against it factors. Reading at the mapping matrix a 1 point is given to the same rows and columns with same variables. It can be observed that promotion is significant at .289 as mapped to nature of work while salary is highly correlated to supervision at .726. Moreover, a fringe benefit at a value of .488 is significant to development and so on.

Table 4.15: The Pair Correlation Matrix of the Different Performance Factors

\begin{tabular}{|c|c|c|c|c|c|c|c|c|c|c|}
\hline & Nature of Work & Supervision & Environment & Reward & Co-Workers & Development & Promotion & Salary & Fringe Benejits & Job Satisfaction \\
\hline Nature of Work & 1.000 & & & & & & & & & \\
\hline Supervision & $-0,364$ & 1.000 & & & & & & & & \\
\hline Environment & -0.452 & -0.250 & 1.000 & & & & & & & \\
\hline Reward & 0.375 & -0.071 & -0.109 & 1,000 & & & & & & \\
\hline Co-Workers & 0.000 & 0.107 & -0.126 & 0.653 & 1.000 & & & & & \\
\hline Development & 0.149 & -0.088 & -0.212 & 0.189 & -0.772 & 1.000 & & & & \\
\hline Promotion & 0.269 & -0.642 & -0.151 & $-0,198$ & 0,142 & 0,000 & 1,000 & & & \\
\hline Salary & $-0,415$ & 0.726 & 0.107 & 0.543 & 0.149 & 0.068 & 0.401 & 1.000 & & \\
\hline Fringe Benefits & 0.000 & -0.085 & 0.325 & -0.462 & 0.184 & 0.488 & -0.229 & 0.457 & 1.000 & \\
\hline Job Satisfaction & $-0,251$ & -0.400 & 0.030 & 0.049 & $-0,013$ & 0.360 & $-0,480$ & -0.223 & 0.243 & 1,000 \\
\hline
\end{tabular}


Based on the results of Table 4.15, the correlation cannot be established by merely pair correlation based on factors mapping alone. An overall correlation must be established which done by using regression analysis and Friedman's analysis of variance or ANOVA. The overall coefficient for multiple correlations using regression analysis is .765. as shown in Table 4.16. It also shows that the (regression squared) $R^{2}$, passed the minimum requirements at .585. R-squared is a statistical measure of how close the data are to the fitted regression line. It is also known as the coefficient of determination, or the coefficient of multiple determination for multiple regression. The higher the R-squared, the better the model fits your data. $R^{2}$ can be interpreted as the percentage of variance in the dependent variable that can be explained by the predictors; as above, this is also true if there is only one predictor. There are nine observable items with 7 regression data to be correlated with a total of eight degree of freedom

To justify the overall acceptabiility, and thru the help of Friedman's ANOVA at .05 alpha and $95 \%$ confidence level, it can be seen that the null hypothesis is rejected and can be states that the different factors have direct correlation. The F computed value is .2016 while the tabulated is 3.798 thus the alternative hypothesis is accepted. To further illustrate the correlation of the different factors, $p$-value is extracted and the salary is the highest factors to be considered at .95 followed by environment at .92 , promotion at .86 and etc.

\section{Proposed Job Satisfaction Model}

To begin with, job satisfaction refers to "the pleasurable emotional state resulting from the appraisal of one's job as achieving or facilitating the achievement of one's job values" (Locke, 1969, p. 316). Similar with this, Brief (1998) defined job satisfaction as a personal state that is demonstrated by affection and cognition evaluating an encountered job with some extent of like or dislike(Whitman, Rooy, and Viswesvaran, 2010).

The researchers focus and look for some characteristics that can mediate and moderate the job satisfaction-job performance relationship and its interdependence. For instance, Zhang and Zheng (2009) argued that the job satisfaction-job performance relationship is mediated by affective commitment to the organization, and the connection between job satisfaction and affective commitment. The model suggests that a reciprocal connection and the existence of the mediators and moderators to the relationship is important. Employee job satisfactions know their performance and vice versa. This state of interdependence also moderated and mediated by many factors depending on particular contexts and conditions occurred.

Figure 4.1 shows the mapping of the job satisfaction and job performance where during job satisfaction can lead to high success and achievement, high self efficacy, goal seeking individual and always in positive mode. In the job performance it was driven by rewards and incentives, belongingness or aggregation, achievements and job well done. 


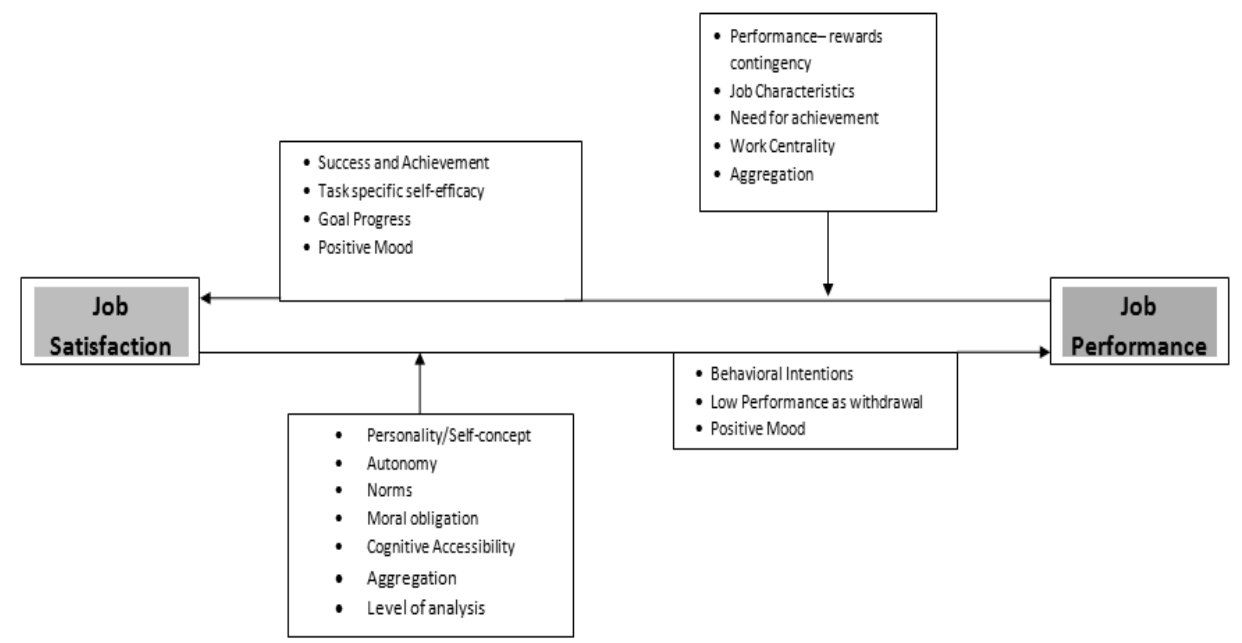

Figure 4.1 Proposed Job Satisfactions and Job Performance Mapping

In the meantime, the more convincing finding of the relationship emerged from the research on the organizational level where it can be asserted that the linkage between job satisfaction and job performance on the collective level was moderately strong. In fact, this finding confirmed the famous statement that 'organizations with more satisfied employees tended to be more effective than organizations with less satisfied employees' (Ostroff, 1992). Therefore, based on the findings and the proposed mapping of job satisfaction and job performance, the researcher encouraged employees to be more proactive in the organization and performed well so that the organization will be motivated to give or increase other incentives and many other remuneration factors to the their employees. In return, employees will continue to deliver quality output for the organization.

\section{DISCUSSION}

The respondents perception on administrators' empowerment that support job satisfaction in terms of administrator as a manager, a corporate leader, fiscal manager, and link between company and community relation that they were "very much empowered. "The respondents' satisfaction affected their job performance in terms of nature of work, supervision, operating condition, contingent reward, co-workers, professional development, promotion, pay and fringe benefits. The following are the factors identified by the respondents that affects job performance; release of incentives, salary increase, change management, slow turnover, staff development, remuneration package, limited leave, no work no pay and other.

A job satisfaction model was developed on the basis of the findings of the study.

Based on the findings and conclusions, the following recommendations are offered: PACUCOA, PAASCU and ACSCU should identify or links with Private companies, Government Organizations and Non-Government Organizations for fund sourcing and to help some member schools to apply for accreditation in a low cost. Currently, the geographical location of the company is not convenient with many employees. With this, 
the administration should plan for possible relocation of the office not only for the benefit of their employees but of course for all member schools. Administration should revisit the current policy. Allow their employees to enjoy freedom in their place of work so that many employees become extremely satisfied in their job, Security of tenure of all regular employees must be reviewed and implemented. The administration must revisit, evaluate, and implement changes for the following: Retirement benefits, Regularization of employees, and Turn-over procedure of employees, Send all employees to different trainings/seminars for personal and professional growth, and The administration should give more time on the implementation of the changes so that the employees can copeup with the new changes/tasks Strict implementation of paperless environment such as submission of reports, letters, invitation and the like on-line must be observed by all employees, administrators, commissioners, accreditors and all member schools. The administration should properly monitor the performance of each employee. Give the regular status to deserving employee who served PACUCOA, PAASCU and ACSCU for at least six (6) months.

\section{References}

Abraiz, A., Tabassum, T.M., and Raja, S. (2012). Empowerment effects and employees job satisfaction. Academic Research International. Vol. 3, No. 3

Chand, S. (2015). Elements of empowerment. Retrieved February 11, 2016 from http://www.yourarticlelibrary.com/human-resources/4-basic-elements-of-

empowerment-in-an-organisations/2440/

Conger, J.A. and Kanungo, (1988). The empowerment process. Academy of management review, vol. 13 No. 3, pp. 471-82.

George, E. (2014). Employees' perception of empowerment: a comparative study among different sectors of banks. International Journal of Services, Management and Economics. Volum 6, Issue No. 2

Greasly, K., Brayman, A., \&Dainti, A. (2010). Employee perception of empowerment. Retrieved July 7, 2016 from

http://www.emeraldinsight.com/doi/abs/10.1108/01425450510605697

Goyne, J., Padgett, D., Rowicki, M.A., \&Triplitt, T. (1999). The journey to teacher empowerment, 1-13.

Hassard, J., Teoh, K., \& Cox, T. (2015). Job satisfaction: theories and definitions. Retrieved July 5,2016 from https://oshwiki.eu/wiki/Job_satisfaction:_theories_and_definitions

Hill, B. (2012). What are the factors affecting job satisfaction.

Retrieved August 2015 from http://smallbusiness.chron.com/factors-affecting-jobsatisfaction-20114.html 
Javed, M., \&Balouch, R., Hassan, F. (2014). Determinants of job satisfaction and its Impact on employee performance and turnover intentions. International Journal of Learning \& Development. Vol. 4, No. 2

Jobstreet.com (2015). 70\% of Filipino employees satisfied with work. Retrieved July 1, 2016 from http://www.jobstreet.com.ph/career-resources/70-filipino-employeessatisfied-work\#.V4DSGuh97IU

Kan, A.H., Nawaz, M.M. (2012). Impact of job satisfaction on employee performance: An empirical study of autonomous Medical institutions of Pakistan.African Journal of Business Management Vol. 6 (7), pp.2697-2705

Kavil, N. (2011) entitled "Factors affecting job satisfaction of pharmaceutical sector. Australian Journal of Business and Management Research Vol.1 No.9 [113-123].

Meyerson, G. (2012). Effect of empowerment on employees performance. Advanced Research in Economic and Management Science (AREMS). Vol.2

Mizne, D. (2015).The Top 10 proven ways to boost employee job satisfaction. Retrieved February 10, 2016 from http://www.15five.com/blog/top-10-proven-ways-to-boostemployee-job-satisfaction/

Nimalathasan, D. (2010) entitled, Job satisfaction and employees' work performance: A case study of people's bank in Jaffna Peninsula, Sri Lanka. Retrieved April 27, 2016 at http://www.mnmk.ro/documents/2010special/5SriLankaBrabeteFFF. pdf

Peters, B.G. and Pierre, J. (2002). Citizens versus the new public manager: the problem of mutual empowerment. Administration \& Society,Vol. 32 No. 1, pp. 9-28.

Pushpakumari, M.D. (2013). The impact of job satisfaction on job performance : An empirical analysis. Date retrieved on June 30, 2016 at http://wwwbiz.meijou.ac.jp/SEBM/ronso/no9_1/08_PUSHPAKUMARI.pdf

Ray, S. \& Ray, I. A. (2011). Human resource management practices and its effect on employees' job satisfaction: A study on selected small and medium sized iron \& steel firms in India. Public Policy and Administration Research. Vol. 1, No.1

Spreitzer, G.M. (1995). Psychological empowerment in the workplace: imensions, measurement, and validation. Academy of Management Journal,Vol. 38 No. 5, pp. 144265.

Sravani, B. S. (2016). 21 Factors that influence employees job satisfaction. Retrieved July 9, 2016 from http://content.wisestep.com/vital-factors-that-influence-employees- jobsatisfaction/

$$
\text { xxxxxxxx----- } x x x x x x x x
$$

